\title{
A Subversive Role for Collaborative Inquiry in Academia Today
}

\author{
Veronika Bohac Clarke \\ University of Calgary \\ bohac@ucalgary.ca
}

\begin{abstract}
The purpose of this article is to speculate about the application of John Heron's concept of Cooperative Inquiry in the context of present day western academic institutions. While this article was written in two institutional locations - one in Canada and the second in Australia, academic contexts in the rest of North America, the UK, and Australia are striking in their similarities. Given the current context of neoliberal policy enacting algorithmic governmentality in education, an application of Co-operative Inquiry as an institutional organizing framework for the work of academics in the humanities, while desirable and possible, would be highly improbable. Since protests and criticisms of the currently ubiquitous policy tend to be muted in view of the risks involved for the protesters, it is suggested that Co-operative Inquiry could be used as a subversive strategy for saving human creative capacity.
\end{abstract}

Keywords: Algorithmic governmentality; corporate university; Co-operative Inquiry; Integral Model; research planning in education

\section{Heron's Revolutionary Idea}

John Heron's Co-operative Inquiry (1996) was a revolutionary concept in the early nineties. In his writing, Heron referenced Ken Wilber's ongoing work on the Integral Model $(1990,1995,1997,2000)$. As such, Heron's thinking was integral and included the recognition of multiple perspectives, which in application implied transdisciplinarity at a time when the traditional scientific paradigm still dominated scholarly debates as the only legitimate approach to research.

Heron's concept of Co-operative Inquiry $(1988,1996)$ was based on the following basic principles: worthwhile practical purpose; democracy and participation; use of many ways of knowing; and emergent developmental form. Heron's requirement for "openness to integral lived experience" (1996, p. 178) could very compatibly support the increasingly transdisciplinary work of scholars in academic institutions, particularly in the humanities. Heron identified four kinds of knowing, which implied different locations in the map of perspectives (quadrants) described by the Integral Model (Wilber, 2006). 

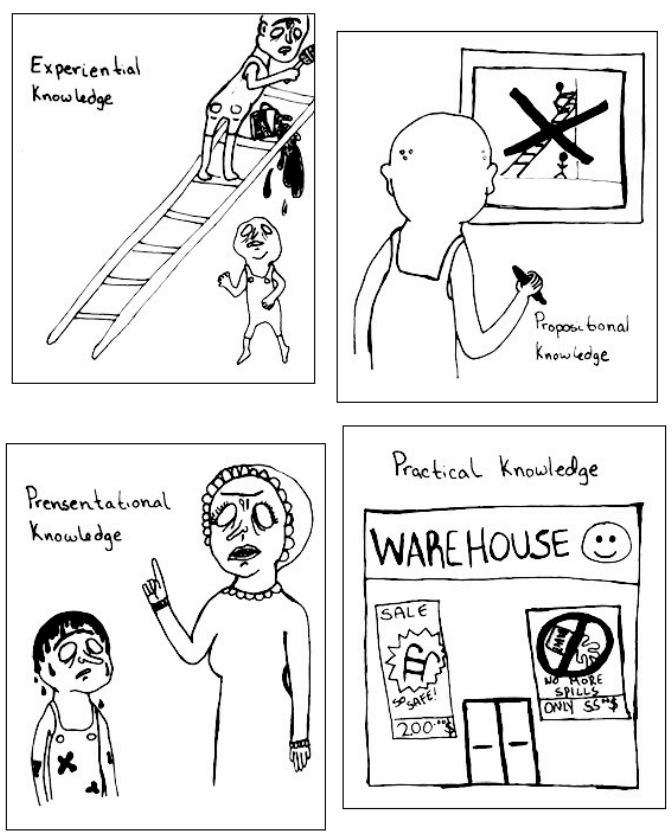

Figure 1. Heron's ways of knowing in the quadrants of the Integral Model.

\section{Integral Look at Heron's Concepts}

A frequent collaborator of John Heron, Peter Reason had teamed up with another integralist, Bill Torbert, in making explicit the integral framework, which had been implicit in Heron's description of Co-operative Inquiry:

...there are multiple ways of knowing and multiple territories to be known, and [that] we can each further the development of our own research/practice (be it a form of social science, of business or political leadership, or an art or craft) with a commitment to engaging, interweaving, and seeking synchrony among more than one mode of knowing across more than one territory. (Reason \& Torbert, 2001, p. 14)

Torbert championed the idea of Co-operative Inquiry as action research science, and advocated for "interdisciplinarity" (which Wilber would call transdisciplinarity). As such, Torbert emphasized that when Co-operative Inquiry is used as action research, there is an interplay between first, second, and third person perspectives (Reason \& Torbert, 2001).

In order to understand the context of Heron's and Torbert's conceptual frameworks, a brief explanation of the map of the territory that inspired - Wilber's $(2000,2006)$ Integral Model - is in order here. The 'quadrant' is the foundational element of the Integral model. Each quadrant represents one of the four fundamental perspectives concerning human development, derived by superimposing two basic dichotomies through which humans observe the world: inside/outside and singular/plural. The quadrants are represented in Figure 2 which follows. The specific importance of the Lower Right quadrant of the model, in relation to the challenges in the current academic context, will be discussed below. 


\begin{tabular}{|c|c|c|}
\hline & INTERIOR & EXTERIOR \\
\hline 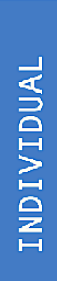 & $\begin{array}{l}\text { UL "What I experience" } \\
\text { "I" - subjective realities } \\
\text { First person } \\
\text { Areas studied: } \\
\text { (e.g., self and consciousness, states of } \\
\text { mind, psychological development, } \\
\text { mental models, emotions, will) }\end{array}$ & $\begin{array}{l}\text { UR "What one does" } \\
\text { "It" - objective realities } \\
\text { Third person } \\
\text { Areas studied: } \\
\text { (e.g., brain and organism, measurable } \\
\text { outcomes, stimulus-response } \\
\text { relationships, efficiency) }\end{array}$ \\
\hline 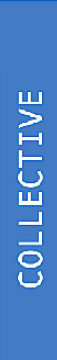 & $\begin{array}{l}\text { LL "What we experience" } \\
\text { "We"(you and I) - } \\
\text { intersubjective realities } \\
\text { Second person } \\
\text { Areas studied: } \\
\text { (e.g., shared values, culture and } \\
\text { worldview, hidden curriculum, } \\
\text { communication, relationships, norms, } \\
\text { boundaries, customs) }\end{array}$ & $\begin{array}{l}\text { LR "What systems do" } \\
\text { "Its" - interobjective realities } \\
\text { Third person } \\
\text { Areas studied: } \\
\text { (e.g., social systems and environment, } \\
\text { visible societal structures, economic } \\
\text { systems, political orders, natural resource } \\
\text { management, ecosystems, planet) }\end{array}$ \\
\hline
\end{tabular}

Figure 2. Wilber's Integral Model (adapted from Bohac Clarke \& Davis, 2017).

The assumptions about the purposes of education inherent in Heron's framework include trust, creativity and emergence. Many academic leaders would respond to this conceptual framework by saying "we are already doing this", and point to "evidence" in terms of numbers and statistics. Yet, when one speaks with academics "in the trenches", their response is quite different. Why are there two different views on how academics do their work?

The Co-operative Inquiry six-step process (Heron, 1996) could be deliberately used by academic managers as an institutional organizing framework and infrastructure for not only research, but also teaching at both the graduate and undergraduate levels. Many professors use their teaching practice as a source of research and theorizing. It would seem that a deliberately integrated co-operative infrastructure could facilitate the unfolding of this work. In the Integral sense, Co-operative Inquiry has the capacity not only to build a strong second-person capacity in the LL (Lower Left) interior collective quadrant, but to pave a way for influencing the disastrous normalizing influences in the LR (Lower Right) systems quadrant.

The Integral quadrants show what could be, as well as what is currently happening in academia from the four basic perspectives. The importance of the LR quadrant is readily apparent on the Integral model's map. Since what is happening in one quadrant also influences what happens in the others, the increasing influence of the systems in the LR on individuals, faculties and universities becomes obvious. In very simple terms, unregulated use and development of technology in the market place, aided by very limited governmental protections of personal information, have created global markets that are driven by voracious hunger for commodifying anything that is commodifiable. These markets have moved into the traditionally government regulated areas of public good, including education. In market terms, education is a product, students are customers, professors are producers, and universities are corporations that compete with other academic corporations which deliver the same products. The purpose of universities has been changed, although the change seems to have gone unnoticed by academic leaders, who are immersed in the heat of the competition. 
Using a collaborative approach in organizations is not a new proposition or a difficult concept in theory, however, its authentic application in practice seems unattainable in current academic contexts in most western countries. In order to address the practical application and challenges to Co-operative Inquiry in academia, I will comment on the current academic context, and endeavour to identify some challenges and barriers.

\section{Academic Context - In Practice}

This trend has been noticed by working academics, so why are scholarly debates on this subject not noticed? Why do leaders in academia seem to be racing to comply with the numbers game, even outpacing the actual demand for 'numbers' and creating new and better ways to measure and represent their 'output'? Why is 'managing professors' behaviour' the new way of interacting between leaders and their academic colleagues? Why does 'algorithmic governmentality' remain a catchy phrase?

While this trend is being debated, or at least written about, so far there does not appear to be a critical mass of critiques to make an impact. One might ask what magnitude of critique would be necessary for impact, and what might be the nature of the impact for the critics. Among the notable critics, Michael Apple has been pointing out the negative effects of the now ubiquitous audit culture for many years, with great eloquence:

In place of a society of citizens with the democratic power to ensure effectiveness and proper use of collective resources, and relying in large measure on trust in the public sector, there emerged a society of 'auditees', anxiously preparing for audits and inspections. A punitive culture of 'league tables' developed (purporting to show the relative efficiency and inefficiency of universities or schools or hospitals). (Apple, 2007, p. 7)

Anderson and Cohen (2015) noted the trend from professional to managerialist values in schools as well as academia (p. 4). They also hinted at the threat that the managerialist approach poses to academics and educators who engage in debate and possibly opposition to the managerialist party line view of professionalism in education:

However, the challenge for both practitioners and scholars is to understand how practitioners move from coping, appropriation, and acts of micro-resistance to collective action within current constraints. What does it mean to be a professional today? Which new forms of accountability are appropriate or inappropriate and why? How should we rethink professionalism for the future? (Anderson \& Cohen, 2015, p. 15)

A final example of 'noticing' and 'speaking up' is a reflection from two academics in the field. In a slim book titled, The Slow Professor, Maggie Berg and Barbara K. Seeber (2016) lament the deleterious effects of the neoliberal managerial efficiency on the quality of thinking and conceptualizing, which are the hallmarks of academic work. The book received accolades and knowing winks at conferences, as well as some criticisms, which could be interpreted in the context of the kind of fear that Michael Apple has been addressing for decades. Yet, as Stephen Ball (2016, p. 1129) reminds us, we are all complicit in what he calls the 'politics of performative truths' and our speech is often less than fearless, as "the 'theoretical silence' of governmentality studies around the issues of resistance and contestation" indicates.

Cultural and Pedagogical Inquiry, Summer 2018, 10(1), pp. 78-89

ISSN 1916-3460 (C) 2018 University of Alberta

http://ejournals.library.ualberta.ca/index.php/cpi/index 


\section{Why is this Governmentality a Problem?}

Aside from the post-truth environment filled with algorithm-enhancing euphemisms, which just cannot be good for human flourishing in general, the across-the-board efficiency also kills creativity. This is summed up succinctly by De Angelis and Harvie (2009) in three words quantification, standardisation, surveillance: "In all cases, chores are imposed and barriers erected that cut across and interrupt the flows of communicational, affective and creative work" (p. 10).

The 'quantification-standardisation-surveillance' approach, make us conservative in our research, even as our rhetoric claims otherwise. They keep us focused on our circumscribed sphere of fundable academic activity, and on teaching and researching by template. This narrowed focus makes looking ahead, being curious, and speculating about the future seem like impractical, time-wasting activities, which, in turn, makes us less than ready to lead education in the fast-approaching post-normal world (Montuori \& Donnely, 2016). A fairly urgent question might be 'what will be the role of education, educators, and academia in a much debated postwork world?' The implications for a changed mandate for educators, are discussed by Danaher (2017) in the context of technological ubiquity, guaranteed income, and a quest for meaningful human existence. Leonardi and Pisani (2017) edited a special journal issue that focuses on the assumptions, ethical and political implications of the implementation of Basic Income. Along with guaranteed income, citizens might have a right to a guaranteed education, in order to support human sanity as well as human flourishing. This would recast the role of education, and present very different requirements for what would constitute teaching and learning. Again, the implications for educators loom large, yet still seem to be taken as theoretical problems in academia.

The 'quantification-standardisation-surveillance' approach, which aims to maximize efficiency, also precludes authentic collegiality. The enforced competition among faculty, where one professor's gain requires another professor's loss, hardly promotes trust. There is no room for the kind of collaborative inquiry and co-creation of knowledge that Heron suggested, in this context.

In many ways, the current rhetoric in academia is reminiscent of the old communist regimes in Europe: with their 5 year plans, the inflated statistics of success, the surveillance, the normalization, the mistrust, and the official slogans and euphemisms, such as 'the rule of the proletariat' (strikingly similar to today's 'transparency'). The European experience also showed that a governance system which does not keep up with the human evolution toward increasing complexity and tries to control, slow down or reverse this process through simplification (in the guise of efficiency), normalization, templates, etc., will eventually collapse. This natural process does not even require a push from accelerationism.

Heron's model of Co-operative Inquiry (1996) could be a practical antidote to this kind of thinking. His approach is designed to develop a group's trust, responsibility, creativity and productivity. In the current academic climate, as discussed above, this approach could be used to create small-scale lacunae for authentic, self-organizing human coexistence. Looking beyond academia, the Co-operative Inquiry model has been succinctly summarized by Reason and Heron on a public web page curated by the University of Bath. This seems to be an example of using Co-operative Inquiry as a public service. It is directed at practitioners, it covers all four Integral 
quadrants - Heron's four ways of knowing - and it specifically addresses the human component inherent in such collaborative interactions. The six procedural steps of Co-operative Inquiry are succinctly summarized for practitioners:

1) Research cycling through all four quadrant ways of knowing.

2) Balance of action and reflection.

3) Developing critical attention.

4) Authentic collaboration, not a hierarchy.

5) Dealing with distress openly in the group.

6) Balancing chaos and order.

Reason and Heron also discuss practical ways of setting up inquiry groups:

1) Initiation.

2) Establishing a group.

3) Contracting.

4) Devising an overall research plan.

5) Roles.

6) Ground rules.

7) Writing.

(Reason \& Heron, n.d.).

The case for using Co-operative Inquiry as an alternative to the increasingly depersonalized, fear based climate in universities, punctuated by the dopamine "likes" of author citations, should be sufficiently clear at this point. The case could also be made for extending Co-operative Inquiry from academia outward. The issue of the increasingly depersonalized digital world, saturated by fake news and social media deliberately manipulated through the use of the dopamine effect, is one that ought to seize the attention of universities, assuming they could recognize it. The principles of Co-operative Inquiry provide one alternative to current online human interactions, and might be actively promoted as such.

This is not to say that universities are silent on current events. In fact, the isegoria that spews from university websites actively uses current events as sound bites for building and reinforcing their corporate brands. This in fact inures the university communities to the reality of the issues. The possibilities of catastrophic global changes are neutered and rendered artificial, in their translation to colourful photo ops and blogs. In the meantime, universities do what corporations do - they hire consultants to build their brand and to organize their activities to enhance their indicators of success. The most sought after consultants seem to be those, whose world view is consistent with the neoliberal governmentality, performativity and the managerial control systems, on which they rely for indicators of compliance and production. These consultants appear to serve Dataism with religious fervor (Harari, 2016). They are the true believers who think like the system which they serve, by helping universities and faculties fall in line with the algorithmic governmentality, in ways that the system will most reward. Ironically, neither Dataism's intrepid early adopters, nor the universities who hire them, seem to be aware that they are accelerating toward their own irrelevance. 


\section{A Suggestion for Action}

Perhaps the academia, and faculties of education in particular, should take a subversive turn and begin cultivating pockets of creativity and complexity, protected within their efficient and approved corporate structures.

Instead of taking advice on how to enhance the numbers on the performance indicators, from neoliberal true believers, faculties of education might consider taking advice from consultants who operate at one developmental level above the true believers. Assuming Wilber's (2000, 2006) principle of 'transcend and include', such individuals would have access to a more complex conception of the world, while also being able to understand the world view of the neoliberal true believer developmental level. These consultants could earn their high salaries by advising faculties how to build in "structures of possibility" into the neoliberal strategy for success. These buffer structures could protect, encourage and respect free inquiry - and address topics that may be on the human horizon, albeit not on the list of approved and fundable research topics. An unfettered look at the possible futures of education, unfiltered by managerialist groupthink, might make significant contributions to the future of academia, education, as well as to humanity.

Ironically, the original Academy established by Plato was a buffer zone - where a form of Co-operative Inquiry was practiced, often through dialectics, its members protected through a closed membership policy, in view of the execution of Socrates.

Lest one become too optimistic, a realistic conversation between a current LeaderManager and VBC (the advocate for Co-operative Inquiry) is more likely to look like this:

LM: How would this buffer zone work, and isn't it simply what we are doing already in the official, approved, transparent structure?

VBC: Faculty members would not be forced to compete to participate in this Co-operative research. They would receive credit for participating - or be 'workloaded' for this segment of their work. No grading, competing, assessing would be involved - just participating in collaborative research of some sort with their peers.

LM: That's crazy - faculty members would just slack off and do nothing, while getting credit for it.

VBC: Indeed you should give faculty members credit - for being self-directed adults. If you treat faculty members as little children whose 'behaviour must be managed', then, indeed, they may end up living down to your expectations, and disengage. Is this not what we teach our pre-service teachers - 'Keep your expectations high and students will live up to them'? So why treat faculty members like children?

LM: That still does not explain how faculty members will be accountable.

VBC: In a Co-operative Inquiry setting, members are accountable to each other, and they self-organize. Genuine, in your face, personal accountability is often much more binding than the fear based managerial accountability. Some faculty members may elect not to participate, and they should be free to make that choice.

LM: You are being impractical. Try wearing my shoes for a day, and then we'll talk. 

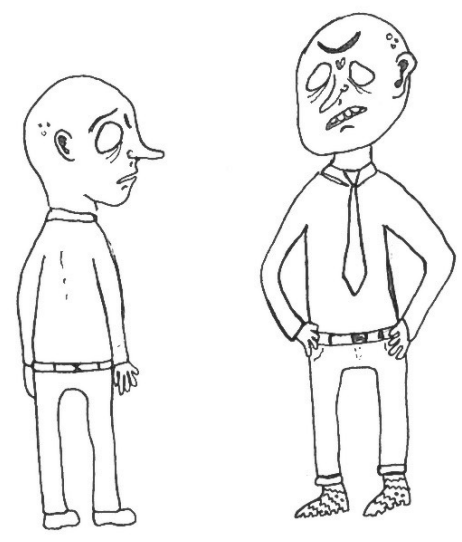

Figure 3. Wearing my shoes.

Wearing the Leader-Manager's shoes entails checking the school league tables often. The key indicators of "number of publications" and "total amount of grant money obtained" dominate the agenda. The goal is getting grants, not doing good research. A paper is a papercount them all - it is the total that counts. To get research grants, simplify the research agenda. Many Humanities faculties in Australia, Britain and North America are adopting the strategy of normalization and reduction of research agendas to a small number of teams, each headed by a thought lead, and dedicated to maximizing grant acquisition. In the case of Canada, I am not sure that these are the outcomes that the Social Sciences and Humanities Research Council (SSHRC) Knowledge Synthesis Report anticipated (Altass \& Wiebe, 2017).

The grant-snagging strategy does not automatically ensure good research - in fact, it ensures propagation of narrow agendas, which will become increasingly protected when grants are received, and not open to critical examination or easy change. Beyond that, faculty members, who are the "producers" are also subject to targets in a competitive zero sum assessment structure. The groups of researchers assigned to a research program with a hierarchical structure, are therefore politely jostling for position with their competitors, while enacting fake collegiality. Peter Senge famously used to say that when one encounters people behaving badly, one should look to the leadership system of the organization. People will behave badly. Historically, the moral cost of this kind of systematic erosion of trust has spread well beyond the individuals - as Václav Havel often reminded the Czech populace in his weekly radio broadcasts, this enforced erosion of trust eventually gnaws at the moral fibre of the nation.

Having examined the Leader-Manager's shoes, let's talk about a realistic proposal. I am not suggesting forming cabals of heroic resistors or saboteurs - if past experience predicts correctly, the system will collapse on its own. I am suggesting a deliberate mechanism for retaining some capacity for trust, clear thinking unclouded by fear, parrhesia with a compassionate focus, as well as creativity, so that the organization could better make the transition to a future context after the evolutionary readjustment. For example, in addition to, say, three grant-oriented research teams, there would be a fourth team, perhaps called Start-ups.

Clearly, given the description of the current conditions in academia, it would be highly unlikely for the Leader-Managers to agree to greenhouse a Startups group - that privilege is 
reserved for the SSHRC grant hunting groups. There would be a price to pay, perhaps a significant price, for establishing a Startups group. In reality, this would be more akin to the Neutral Zone, rather than a buffer zone. The establishment of the Startups would require negotiations for some minimal amount of funding for conference travel, which would be essential for networking and exchange of ideas across the country. Since the Startups would not have the support behind them for leveraging SSHRC grants, it is likely that they would only be garnering small, targeted grants, which would certainly not include travel expenses. Next, there would need to be some agreement about the legitimacy of this group, so that the Startups would not be treated as upstarts in the organization. The work and achievements of the Startups would not be set up to compete with the SSHRC groups. Additionally, in the absence of SSHRC grants, the members of Startups would not have teaching releases, and would have to be prepared to shoulder heavy teaching loads. Finally, if the institutional performance assessment rubrics specifically list SSHRC or large scale grants, the members of the Startups would need to accept some negative evaluations - at least until they became established and successful on their own.

In return, the members of the Startups would be able to self-organize and pursue a variety of projects, both individually and in small groups. The sharp blade of competition would be blunted, and everyone would have equal voice to wield without recrimination. The goal would be to pursue new, unique or unusual research topics, and to promote and create publication venues for this kind of work. It would be highly recommended that Heron's Co-operative Inquiry process be followed, particularly because of its support for the healthy unfolding of the human element. Considering the price of admission, it is likely that those with casual interest or curiosity would not apply for membership, thereby providing some assurance of forming a committed group of individuals.

\section{A Hopeful Conclusion}

From an obstinately hopeful perspective, in the sanctity of that buffer zone, it may yet be possible for professors to enact a Heronian look in the eye of their colleagues and deans, and make parrhesia (Ball, 2016) a common means of communication. New knowledge might be coconstructed.

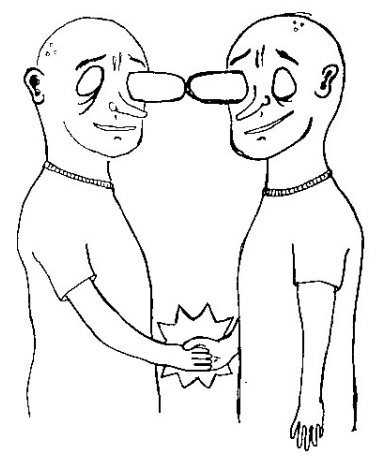

Figure 4. Heron's Look in the Eye Co-operative Inquiry. 
I believe, along with Montuori and Donnely (2016), that many academics share the hope that creativity and collaboration are possible in academia:

Creativity has become a vital and much-discussed topic in the post-normal world. The historical focus on individual creativity is being complemented by a new interest in collaborative creativity, in business, culture, and academia. New questions are arising about such topics as creativity in relationships and groups, and creative networks. (pp. 758-759)

While my tone throughout this article has been mostly critical, in order to point out some of the shortcomings of the current managerial view of the work of academics, I also acknowledge that advocacy fuelled by positive energy is needed to make change a possibility. A positive vision of change would include genuine trust, fearless collaboration, creativity and a playful spirit of inquiry leading to emergent developmental forms. 


\section{References}

Altass, P., \& Wiebe, S. (2017). Re-imagining education policy and practice in the digital era. Journal of the Canadian Association for Curriculum Studies, 15(2), 48-63.

Anderson, G. \& Cohen, M. I. (2015). Redesigning the identities of teachers and leaders: A framework for studying new professionalism and educator resistance. Education Policy Analysis Archives, 23(85).

Apple, M. (2007). Education, markets, and an audit culture. International Journal of Educational Policies, 1(1), 4-19.

Ball, S. (2016). Subjectivity as a site of struggle: refusing neoliberalism? British Journal of Sociology of Education, 37(8), 1129-1146.

Berg, M. \& Seeber, B. (2016). The slow professor: Challenging the culture of speed in the academy. Toronto, ON: University of Toronto Press.

Bohac Clarke, V. and Davis, B. (2017). "To Integralville and back again: The story of graduate students' journey toward understanding and enacting the Integral Model in their research." Paper for the Canadian Association for Curriculum Studies, presented at the Congress of the Humanities and Social Sciences, Annual Conference of The Canadian Society for the Study of Education, May 28-June 1, 2017, Toronto, Ontario.

Danaher, J. (2017). Building a post-work utopia: Technological unemployment, life extension and the future of human flourishing. In K. LaGrandeur \& J. Hughes (Eds.), Surviving the machine age: Intelligent technology and the transformation of human work (pp. 63-82). Palgrave-MacMillan. Retrieved from: https://link.springer.com/chapter/10.1007/978-3-319-51165-8_5

De Angelis, M. \& Harvie, D. (2009). 'Cognitive capitalism' and the rat-race: How capital measures immaterial labour in British universities. Historical Materialism, 17(3), 3-30.

Harari, Y. (2016). Homo deus: A brief history of tomorrow. London: Vintage Publishing.

Heron, J. (1988). Validity in Co-operative inquiry. In P. Reason (ed.), Human Inquiry in Action (pp. 40-59). London: Sage Publications.

Heron, J. (1996). Co-operative inquiry: Research into the human condition. London: Sage Publications.

Leonardi, E. \& Pisani, G. (2017). Basic income. Guest editors preface. Etica \& Politica / Ethics \& Politics, 19(1), 7-10.

Montuori, A. \& Donnelly, G. (2016). The creativity of culture and the culture of creativity research: The promise of integrative transdisciplinarity. In V.P. Gla veanu (ed.), The Palgrave handbook of creativity and culture research (pp. 743-765). Palgrave Macmillan. Retrieved from: http://lib1.qsm.ac.il/books/70620.pdf 
Reason, P. \& Heron, J. (n.d.). A layperson's guide to co-operative inquiry. Retrieved from: https://wagner.nyu.edu/files/leadership/avina_heron_reason2.pdf

Reason, P. \& Torbert, W. (2001). The action turn: Toward a transformational social science. Concepts and Transformation, 6(1), 1-37.

Wilber, K. (1990). Eye to Eye: The quest of the new paradigm. Boston, MA: Shambhala.

Wilber, K. (1995). Sex, ecology, spirituality: The spirit of evolution. Boston, MA: Shambhala.

Wilber, K. (1997). The eye of spirit. Boston, MA: Shambhala.

Wilber, K. (2000). Integral psychology. Boston, MA: Shambhala.

Wilber, K. (2006). Integral spirituality. Boston, MA: Shambhala.

\section{Author's Note:}

Cartoon illustrations by Gabrielle Clarke were not intended to represent specific genders or other details. The emphasis was on the overall enacted meaning of the cartoon. 